\title{
Predictive performance and clinical utility of HCC risk scores in chronic hepatitis C: a comparative study
}

\author{
Gamal Shiha ( $\sim$ g_shiha@hotmail.com) \\ Nabiel NH Mikhail \\ Egyptian Liver Research Institute and Hospital \\ Reham Soliman \\ Egyptian Liver Research Institute and Hospital \\ Ayman Hassan \\ Egyptian Liver Research Institute and Hospital \\ Mohammed Eslam \\ Westmead Institute for Medical Research
}

Egyptian Liver Research Institute and Hospital https://orcid.org/0000-0002-9338-8854

\section{Research Article}

Keywords: HCV, SVR, Cirrhosis, HCC, HCC surveillance, Individual risk, Clinical utility, Applicability, Score Performance, AFP

Posted Date: July 8th, 2021

DOI: https://doi.org/10.21203/rs.3.rs-608122/v1

License: (c) (1) This work is licensed under a Creative Commons Attribution 4.0 International License. Read Full License

Version of Record: A version of this preprint was published at Hepatology International on January 16th, 2022. See the published version at https://doi.org/10.1007/s12072-021-10284-6. 


\section{Abstract}

\section{Background and aim:}

Many HCC risk prediction scores were developed to guide HCC risk stratification and identify $\mathrm{CHC}$ patients who either need intensified surveillance or may not require screening. There is a need to compare different scores and their predictive performance in clinical practice.

We aim to compare the newest HCC risk scores evaluating their discriminative ability, and clinical utility in a large cohort of $\mathrm{CHC}$ patients.

\section{Patients and methods}

The performance of the scores was evaluated in $3075 \mathrm{CHC}$ patients who achieved SVR following DAAs using Log rank, Harrell's c statistic, also tested for HCC-risk stratification and negative predictive values.

\section{Results}

HCC developed in 212 patients within 5 years follow up. Twelve HCC risk scores were identified and displayed significant Log rank ( $p \leq 0.05)$ except Alonso-Lopez TE-HCC, and Chun scores where $(p=0.374, p=0.053$ respectively). Analysis of the remaining ten scores revealed that ADRES, GES pre-post treatment, GES algorithm and Watanabe (post-treatment) scores including dynamics of AFP, were clinically applicable and demonstrated good statistical performance; Log rank analysis < 0.001, Harrell's C statistic $(0.66-0.83)$ and high negative predictive values $(94.38-97.65 \%)$. In these three scores, the 5 years Cumulative IR in low risk groups is very low $(0.54-1.6)$ so, screening could be avoid safely in these patients.

\section{Conclusion}

ADRES, GES score, GES algorithm and Watanabe (post-treatment) scores seem to offer acceptable HCC-risk predictability and clinical utility in CHC patients. The dynamics of AFP as a component of these scores may explain their high performance when compared to other scores.

Word count: 250

\section{Introduction:}

Chronic hepatitis $\mathrm{C}$ infection is a major public health problem with an estimated 71 million persons chronically infected with hepatitis $\mathrm{C}$ worldwide [1]. Hepatitis $\mathrm{C}$ virus (HCV) may lead to hepatocellular carcinoma (HCC), with an annual incidence of approximately 3-8 percent in cirrhotic patients [2]. The use of very effective and safe direct acting antivirals (DAAs) had scaled up the management of chronic HCV patients particularly in patients with liver cirrhosis and advanced hepatic fibrosis. Millions of patients with HCV infection are expected be treated over the next decade. viral clearance after DAAs lowered but did not completely end the occurrence of HCC in post-SVR patients [3-6].

Biannual HCC surveillance by ultrasound with or without alpha-fetoprotein (AFP) in patients with cirrhosis was recommended by many current guidelines [7-8]. An annual incidence of $1.5 \%$ or higher would permit surveillance of HCC [9]. This conclusion was backed up by data indicating curative treatment, improved survival and a higher rate of early diagnosis among patients undergoing screening for HCC [10]. However, 'one-size-fits-all' strategy increases the health care costs particularly in low- to middle-income countries, with a high HCV prevalence, furthermore, it is estimated that a small percentage of patients with cirrhosis are monitored according to guidelines, highlighting the unmet need for an optimal simple score for individualized HCC surveillance [11].

In this context, recently, many HCC risk prediction scores (Table 1) were developed to guide HCC risk stratification and identify CHC patients who either need intensified surveillance or may not require screening. In the literature, there is no data comparing these different scores, consequently there is a need for direct comparison of the performance, applicability, and clinical utility of these HCC risk scores in independent patient populations. This comparison is highly needed to help the health authorities to properly focus resources towards patients at high risk of development of HCC and to avoid screening of patients with very low HCC risk, also, the assessment of these scores will provide data which is necessary to support the mandatory modification of the current guidelines of HCC screening.

Our aim is to evaluate the newest HCC risk scores comparing their discriminative ability, applicability and clinical utility in a large cohort of CHC patients who achieved SVR following DAAs.

\section{Patients And Methods:}

\section{Cohort}

3075 consecutive $\mathrm{CHC}$ patients, with liver cirrhosis (F4) or advanced liver fibrosis (F3) who had a sustained virologic response (SVR) after receiving DAAs were included in this observational study.

From January 2014 till July 2019, patients were recruited from the out-patient clinics at the Egyptian Liver Research Institute and Hospital (ELRIAH) and its satellites throughout the Nile Delta. 
This study was conducted in accordance with the protocol and the principles of the Declaration of Helsinki [12] and its amendments in 2008. The protocol was approved by the Institutional Research Board of ELRIAH (IORG0008819, IRB00010534) in accordance with the local regulations. The need to obtain informed consent from the participants was waived by the IRB due to the retrospective nature of the study.

\section{Patients' evaluation}

All patients in the cohort had their initial data (before treatment) recorded, together with the data in the follow up visits, up to the last follow up. HCC incidence, together with expected HCC incidence data, were also recorded.

\section{Diagnosis of fibrosis and HCC}

According to the standard guidelines, patients were diagnosed as having advanced liver fibrosis ( $\mathrm{F} 3$ ) by transient elastography (>10.2 and $\leq 16.3 \mathrm{kPa}$ ) [13]. While, they were considered to have cirrhosis (F4) when they fulfilled more than one of the following criteria: a) definite clinical signs and laboratory parameters of liver cirrhosis (e.g. splenomegaly, ascites, albumin $\leq 3.5 \mathrm{~g} / \mathrm{dL}$, platelets count $\leq 100 \mathrm{cmm} 3$ ); b) abdominal ultrasonographic signs suggestive of cirrhosis (e.g. mild splenomegaly, minimal ascites, PV dilatation and collaterals); c) transient elastography (> 16.3 kPa).

The diagnosis of HCC was made in accordance with EASL and AASLD guidelines. Multiphase CT or MRI was done to the patient if there were any focal hepatic lesions diagnosed by abdominal ultrasound and /or AFP value $>20 \mathrm{ng} / \mathrm{ml}$. MSCT. Diagnosis of HCC was based on the characteristic arterial enhancement and early washout in delayed phase [14-16].

\section{Scores selection}

We undertook a systematic literature search of PubMed database for studies reporting on HCC prediction scores for HCC over the last 5 years. We used the following search terms: ("Hepatocellular carcinoma" [Mesh] AND "HCV" AND "risk score" [Mesh]. Citations generated by electronic scanning were assessed for relevance based on title, abstracts and key words. Prediction risk scores for which the parameters are available in our cohort were included.

\section{Statistical methods}

Statistical analyses were performed using version 26, SPSS (Statistical Package for Social Sciences) (IBM Corp., USA). The follow up duration was calculated as the time between the end of treatment and the last follow up, or the date of event development (HCC occurrence), whichever occurred first. Times to events and cumulative incidences were calculated with the Kaplan-Meier method.

The performance of the scores was evaluated using:

- Receiver operator curve analysis (ROC) for numeric scores to assess the HCC predictive ability of the score. Accuracy is measured by the area under the ROC curve (AUROC). An area of 1 represents a perfect test; an area of .5 represents a worthless test. A rough guide for classifying the accuracy of a diagnostic test is using 0.7 to indicate fair, 0.8 to indicate good and 0.9 to indicate excellent. Acceptable discrimination is indicated when AUROC is $>0.70[17]$

- Evaluating the performance of the risk stratification as a screening procedure against HCC development as the gold standard. Using the risk stratification results, patients are classified into risky group (intermediate and high risk score) and less-risky group (low risk score) and then performance statistics (sensitivity, specificity, positive predictive value (PPV), negative predictive value (NPV) and accuracy) are calculated. NPV (the probability that subjects with a negative screening test truly do not have the disease) is of special importance in score comparisons [18].

- Log rank (Mantel-Cox) analysis for comparison of incidence curves. P value $\leq 0.05$ was considered significant.

- Harrell's c statistic [19]. The C-statistic only gives a general idea about a model (goodness of fit measure). A value below 0.5 indicates a very poor model. A value of 0.5 means that the model is no better than predicting an outcome than random chance. Values over 0.7 indicate a good model. Values over 0.8 indicate a strong model. A value of 1 means that the model perfectly predicts those group members who will experience a certain outcome and those who will not $[20,21]$.

\section{Comparison of the scores}

The different scores will be evaluated in the same cohort in a stepwise manner:

- Statistical performance of the scores using the above mentioned methods. Scores not significant in log rank test.

- Scores that are statistically valid will be tested for its applicability and its clinical utility by: a) studying its ability to stratify patients into the different risk groups either two groups only (high and low), three groups (high, intermediate and low) or four groups where the low is subdivided into low and very low; b) calculating the percentage of patients in each category together with its 5-year cumulative incidence of HCC; and c) reporting the AUROC and NPV of the score.

\section{Results:}

Using the previously mentioned search criteria, 95 papers resulted.

Score exclusion criteria: 
- Prediction scores that depend on molecular and genetic risk factors which are expensive, not done routinely and were not available for patients in our cohort, like fat-genetic risk score [22], TLL1 [23, 24], IFNL3 [25, 26], MICA [27] and DEPDC5 [28].

- Scores that needs data not routinely available in our dataset, as GGT (FIB4HCC score by Alonso López et al. [29] and Ganne-Carrié et al. [30]).

- Scores that are depending on complicated mathematical methods like ElSerag et al. (HES) score [31] or the methods used for stratification of patients into risk groups was not fully reported in the published papers as loannou et al. score [32].

Accordingly, eleven scores and an algorithm were included in this study (Table 1).

Cohort characteristics:

The study included 3075 chronic HCV patients (1037 patients with F3 and 2038 with F4 stage) with SVR who met the inclusion criteria in our study between January 2014 and July 2019. Characteristics of the patients are shown in supplementary table 1 . The mean observation period was $24.32 \pm$ 12.14 months after the end of DAAs treatment (range 6-72 months). HCC developed in 212 cases during the study period. Characteristics of the patients according to the development of HCC are shown in supplementary table 2. Out of the $212 \mathrm{HCC}$ cases identified during follow-up, 38 occurred during the first year of follow-up, 67 during the second year, 62 during the third year, and 26 during the fourth year, and 19 after the fourth year of follow-up.

Performance of eleven scores and an algorithm was compared and the results were presented in tables 2 and 3, and Fig. 1. Most scores stratified risk of HCC into three strata (low, intermediate and high), except two scores (Alonso López et al. TE-HCC score and Hiraoka et al. ADRES score) that stratified risk into four strata (very low, low, intermediate and high), and two scores (Hu et al. score and Abe et al. score) that stratified risk into two strata (low and high).

Sharma et al. THRI score:

Patients were classified into low risk group (766 patients, 24.9\%), intermediate risk group (2072 patients, 67.4\%) and high risk group (237 patients, $7.7 \%$ ). $\mathrm{HCC}$ developed in 9 of patients belonging to low risk group with 5 years cumulative incidence of $0.51 \%(95 \% \mathrm{Cl}=0.23-1.02), 165$ belonging to intermediate risk group with 5 years cumulative incidence of $3.25 \%(95 \% \mathrm{Cl}=2.73-3.84)$ and 38 belonging to high risk group with 5 years cumulative incidence of $6.47 \%(95 \% \mathrm{Cl}=4.45-9.12)$. Log rank test for comparison of incidence curves is highly statistically significant ( $p<0.001)$, and Harrell's $\mathrm{C}$ statistics was fair (0.6505). This score is considered statistically valid.

Watanabe et al. pre-treatment score:

Patients were classified into low risk group (676 patients, $22.0 \%$ ), intermediate risk group (2077 patients, $67.5 \%$ ) and high risk group (322 patients, $10.5 \%$ ). $\mathrm{HCC}$ developed 6 of patients belonging to low risk group with 5 years cumulative incidence of $0.40 \%(95 \% \mathrm{Cl}=0.10-1.09), 126$ belonging to intermediate risk group with 5 years cumulative incidence of $2.42 \%(95 \% \mathrm{Cl}=1.86-3.09)$ and 80 belonging to high risk group with 5 years cumulative incidence of $8.29 \%(95 \% \mathrm{Cl}=5.95-11.25)$. Log rank test for comparison of incidence curves is highly statistically significant $(p<0.001)$, and Harrell's c statistics was fair (0.6406). This score is considered statistically valid.

Watanabe et al. post-treatment score:

Patients were classified into low risk group (1462 patients, 47.5\%), intermediate risk group (97 patients, 39.9\%) and high risk group (77 patients, $12.9 \%$ ). $\mathrm{HCC}$ developed in 38 of patients belonging to low risk group with 5 years cumulative incidence of $1.10 \%(95 \% \mathrm{Cl}=0.68-1.68)$, 97 belonging to intermediate risk group with 5 years cumulative incidence of $3.11 \%(95 \% \mathrm{Cl}=2.33-4.08)$ and 77 belonging to high risk group with 5 years cumulative incidence of $7.58 \%(95 \% \mathrm{Cl}=5.44-10.30)$. Log rank test for comparison of incidence curves is highly statistically significant ( $p<0.001)$, and Harrell's $\mathrm{c}$ statistics was fair (0.6693). This score is considered statistically valid.

Hu et al. score:

Patients were classified into low risk group (1814 patients, $59.0 \%$ ) and high risk group (1261 patients, $41.0 \%$ ). HCC developed in 70 of patients belonging to low risk group with 5 years cumulative incidence of $1.70 \%(95 \% \mathrm{Cl}=1.29-2.19)$, and 142 belonging to high risk group with 5 years cumulative incidence of $4.60 \%(95 \% \mathrm{Cl}=3.80-5.51)$. Log rank test for comparison of incidence curves is highly statistically significant $(p<0.001)$, and Harrell's c statistics was fair (0.6158). This score is considered statistically valid.

Tani et al. score:

Patients were classified into low risk group (2178 patients, 70.8\%), intermediate risk group (885 patients, 20.8\%) and high risk group (12 patients, $0.4 \%$ ). $\mathrm{HCC}$ developed in 94 of patients belonging to low risk group with 5 years cumulative incidence of $2.13 \%(95 \% \mathrm{Cl}=1.73-2.59), 116$ belonging to intermediate risk group with 5 years cumulative incidence of $6.48 \%(95 \% \mathrm{Cl}=5.38-7.77)$ and 2 belonging to high risk group with 5 years cumulative incidence of $11.48 \%(95 \% \mathrm{Cl}=1.93-37.93)$. Log rank test for comparison of incidence curves is highly statistically significant ( $\mathrm{p}<0.001)$, and Harrell's $\mathrm{C}$ statistics was fair (0.6388). This score is considered statistically valid.

Fan et al. aMAP score:

Patients were classified into low risk group (521 patients, $16.9 \%$ ), intermediate risk group (1315 patients, $42.8 \%)$ and high risk group (1239 patients, $40.3 \%)$. HCC developed in 4 of patients belonging to low risk group with 5 years cumulative incidence of $0.35 \%(95 \% \mathrm{Cl}=0.09-0.95), 38$ belonging to intermediate risk group with 5 years cumulative incidence of $1.17 \%(95 \% \mathrm{Cl}=0.79-1.68)$ and 170 belonging to high risk group with 5 years cumulative 
incidence of $5.40 \%(95 \% \mathrm{Cl}=4.50-6.44)$. Log rank test for comparison of incidence curves is highly statistically significant ( $p<0.001)$, and Harrell's $\mathrm{C}$ statistics was fair (0.6984). This score is considered statistically valid.

Hiraoka et al. ADRES score:

Patients were classified into very low risk group (504 patients, $16.4 \%$ ), low risk group (1244 patients, $40.5 \%$ ), intermediate risk group (1032 patients, $33.6 \%$ ) and high risk group (295 patients, 9.6\%). HCC developed in 6 of patients belonging to very low risk group with 5 years cumulative incidence of $0.54 \%(95 \% \mathrm{Cl}=0.14-1.46), 36$ of them belonging to low risk group with 5 years cumulative incidence of $1.18 \%(95 \% \mathrm{Cl}=0.72-1.83), 96$ belonging to intermediate risk group with 5 years cumulative incidence of $3.64 \%(95 \% \mathrm{Cl}=2.72-4.79)$ and 74 belonging to high risk group with 5 years cumulative incidence of $9.08 \%(95 \% \mathrm{Cl}=6.49-12.38)$. Log rank test for comparison of incidence curves is highly statistically significant ( $<<0.001)$, and Harrell's $\mathrm{c}$ statistics was fair (0.7183). This score is considered statistically valid.

Abe et al. score:

Patients were classified into low risk group (2604 patients, 84.7\%) and high risk group (471 patients, 15.3\%). HCC developed in 136 of patients belonging to low risk group with 5 years cumulative incidence of $2.51 \%(95 \% \mathrm{Cl}=2.00-3.10)$, and 76 belonging to high risk group with 5 years cumulative incidence of $6.43 \%(95 \% \mathrm{Cl}=4.76-8.50)$. Log rank test for comparison of incidence curves is statistically significant $(p=0.013)$, and Harrell's c statistics was fair (0.5678). This score is considered statistically valid.

Shiha et al. GES score:

a - Pre-treatment score

Patients were classified into low risk group (1857 patients, 60.4\%), intermediate risk group (719 patients, 23.4\%) and high risk group (499 patients, $16.2 \%$ ). $\mathrm{HCC}$ developed in 59 of patients belonging to low risk group with 5 years cumulative incidence of $1.66 \%(95 \% \mathrm{Cl}=1.27-2.12), 71$ belonging to intermediate risk group with 5 years cumulative incidence of $4.45 \%(95 \% \mathrm{Cl}=3.50-5.57)$ and 82 belonging to high risk group with 5 years cumulative incidence of $7.64 \%(95 \% \mathrm{Cl}=6.11-9.43)$. Log rank test for comparison of incidence curves is highly statistically significant ( $p<0.001)$, and Harrell's $\mathrm{C}$ statistics was good $(0.801)$. This score is considered statistically valid.

b - Post-treatment score

Patients were classified into low risk group (1764 patients, 57.4\%), intermediate risk group (944 patients, $30.7 \%$ ) and high risk group (367 patients, $11.9 \%$ ). $\mathrm{HCC}$ developed in 46 of patients belonging to low risk group with 5 years cumulative incidence of $1.35 \%(95 \% \mathrm{Cl}=1.00-1.79), 68$ belonging to intermediate risk group with 5 years cumulative incidence of $3.49 \%(95 \% \mathrm{Cl}=2.73-4.40)$ and 98 belonging to high risk group with 5 years cumulative incidence of $11.09 \%(95 \% \mathrm{Cl}=9.05-13.45)$. Log rank test for comparison of incidence curves is highly statistically significant ( $<<0.001)$, and Harrell's c statistics was good (0.828). This score is considered statistically valid.

Shiha et al. GES algorithm:

Patients were classified into low risk group (1574 patients, 51.2\%), intermediate risk group (609 patients, 19.8\%) and high risk group (892 patients, $29.0 \%$ ). $\mathrm{HCC}$ developed in 37 of patients belonging to low risk group with 5 years cumulative incidence of $1.23 \%(95 \% \mathrm{Cl}=0.88-1.67)$, 38 belonging to intermediate risk group with 5 years cumulative incidence of $2.93 \%(95 \% \mathrm{Cl}=2.11-3.99)$ and 137 belonging to high risk group with 5 years cumulative incidence of $7.15 \%(95 \% \mathrm{Cl}=6.03-8.43)$. Log rank test for comparison of incidence curves is highly statistically significant $(\mathrm{p}<0.001)$, and Harrell's $\mathrm{c}$ statistics was good (0.832). This algorithm is considered statistically valid.

Chun et al. HCC-SVR score:

Patients were classified into low risk group (957 patients, 31.1\%), intermediate risk group (1659 patients, 54.0\%) and high risk group (459 patients, $14.9 \%$ ). $\mathrm{HCC}$ developed in 31 of patients belonging to low risk group with 5 years cumulative incidence of $1.75 \%(95 \% \mathrm{Cl}=1.21-2.45), 120$ belonging to intermediate risk group with 5 years cumulative incidence of $3.52 \%(95 \% \mathrm{Cl}=2.92-4.21)$ and 61 belonging to high risk group with 5 years cumulative incidence of $5.79 \%(95 \% \mathrm{Cl}=4.47-7.39)$. Log rank test for comparison of incidence curves is not statistically significant ( $p=0.053)$, and Harrell's $\mathrm{C}$ statistics was fair (0.6038).

Alonso López et al. TE-HCC score:

Patients were classified into very low risk group (490 patients, 15.9\%), low risk group (848 patients, 27.6\%), intermediate risk group (1236 patients, $40.2 \%$ ) and high risk group (501 patients, 16.3\%). HCC developed in 15 of patients belonging to very low risk group with 5 years cumulative incidence of $1.09 \%$ $(95 \% \mathrm{Cl}=0.44-2.27), 42$ of them belonging to low risk group with 5 years cumulative incidence of $1.82 \%(95 \% \mathrm{Cl}=1.10-2.85), 98$ belonging to intermediate risk group with 5 years cumulative incidence of $2.90 \%(95 \% \mathrm{Cl}=2.10-3.90)$ and 57 belonging to high risk group with 5 years cumulative incidence of $3.65 \%(95 \% \mathrm{Cl}=2.37-5.39)$. Log rank test for comparison of incidence curves is not statistically significant ( $p=0.374)$, and Harrell's $\mathrm{C}$ statistics was fair (0.5975)

\section{Discussion:}


Direct comparison of the predictive performance and clinical utility of HCC risk scores in the same patient population have been recently reported in chronic hepatitis B [43]. To the best of our knowledge, this work is the first comparative study assessing the predictive performance of many HCC risk scores in the same large cohort of CHC patients who achieved SVR following DAAs with follow up period of more than 5 years. Most of these scores showed acceptable performance for HCC prediction in our cohort and were able to stratify CHC patients into low and risky groups.

All the studied HCC risk scores displayed reasonable statistical performance with significant Log rank (Mantel-Cox) analysis for comparison of incidence curves ( $p$ value $\leq 0.05$ ) except TE-HCC score of Alonso-Lopez et al [29], and Chun et al [42] where ( $p=0.374, p=0.053$ respectively). The scores of Sharma et al (THRI score) [33], Watanabe et al (pre-treatment) [34] and Fan et al (aMAP score) [37] revealed strong statistical performance with highly significant Log rank ( $<<0.001$ ), Harrell's c statistic $\geq 0.64$, area under the ROC curve (AUROC) values $\geq 0.73$ and very high negative predictive values $(>98 \%$ ). However, these scores stratified less than $25 \%$ of our cohort into the low risk group suggesting the need for HCC surveillance in the remaining $75-85 \%$ of patients. Including the majority of patients in the screening will not only lead to a diminished cost-effectiveness of surveillance program but also may impose substantial physical harms on patients including multiple CT/MRI. Recently Fan et al. agreed that stratifying most of the patients into the high and intermediate risk groups based on the aMAP score, would reduce the cost-effectiveness of the surveillance [44]. This finding showed that good statistical performance of any HCC risk score may not be directly translated to clinical usefulness. It is interesting that the same observation was emphasized during comparison of HCC risk scores in CHB [43].

Conversely, the score of Tani et al. [36] and Abe et al. [39], stratified most of the patients $70.8 \%-84 \%$ into the low risk group with 5 years cumulative IR (95\% $\mathrm{Cl})$ of 2.13 (1.73-2.59) and 2.51 (2.00-3.10) respectively which is higher than all studied scores. A large number stratified into the low risk group means that a lot of risky patients will not be screened, consequently many HCC cases will be missed, so HCC surveillance cannot be safely avoided.

Five scores are remaining, Watanabe et al. (post-treatment) [34], HU et al. score [35], GES score [40], GES algorithm [41] and ADRES [38]; the score of Hu et al. stratified the patients into two categories only low and high-risk groups, consequently, a large number (41\%) of our patient cohort should undergo more intense screening which may lead to reduced cost-effectiveness and increased physical harms. Screening of this large number of patients using HU et al. score could be explained by the lack of an intermediate risk group, highlighting the importance of this group during application of HCC risk scores in clinical practice.

Finally, after evaluation and comparison of these twelve HCC risk scores we ended with four scores namely Watanabe et al (post-treatment), GES score, GES algorithm and ADRES score. These scores were clinically applicable being simple, easy to calculate and based on readily available clinical and laboratory parameters. In addition, these scores demonstrated good statistical performance; Log rank analysis $<0.001$, Harrell's C statistic (0.66-0.83) and high negative predictive value (94.38-97.65\%). Also, these scores stratified our patients successfully into low, intermediate, and high groups with very low 5 yrs cumulative IR (0.54-1.6) in the low risk group which is about $50 \%$ of the cohort, so surveillance could be avoided safely in approximately half of the patients. On the other hand, the high-risk groups had high 5 yrs cumulative IR in about $20 \%$ of the patients only, for whom more intense screening may be required. The three scores had intermediate risk group with relatively high 5 yrs cumulative IR in about one third of patients who may need to continue screening according the current guidelines.

The good performance of GES score and algorithm may be explained not only by the fact that it was derived from a similar population with the same HCV genotype but also that it included both F4 and F3 in its components [40, 41]. It should be noted that the study cohort included both patients with F3 and F4 as well as the cohorts from which Watanabee et al. [34] and ADRES [38 ] scores were derived as FIB-4 > 3.25 i.e. F3 and F4.

There was a debate about HCC surveillance after SVR in individuals with cirrhosis (F4) vs. pre-cirrhotic advanced fibrosis (F3). EASL supports ongoing surveillance in patients with advanced fibrosis (F3) whereas AASLD does not [7]. loannou in his recent review of HCC surveillance after SVR in patients with F3 and F4 explained this point by reporting that this disagreement is due to the difficulty in precise determination of patients with $\mathrm{F} 3$ fibrosis and the fact that they are a heterogeneous group with some patients having F3-F4 fibrosis and higher HCC risk and others having F2-F3 fibrosis with lower risk. Furthermore, certain patients are under staged by biopsy or non-invasive markers of fibrosis and hence their risk of HCC is underestimated [11]. Advanced fibrosis (F3) leading to HCC often diagnosed at late stages due lack of screening which lead to a significant gap in real life clinical care. As a result, there is a need for models to identify patients with F3 who have a high enough HCC risk that warrant HCC surveillance.

It is not clear why Watanabe et al (post-treatment) and ADRES scores had good statistical performance and clinical utility in our cohort although they were derived from totally different population and genotypes. However, careful analysis of the components of these scores showed that they are very similar including age, fibrosis stage and AFP; this similarity of the components of these HCC risk scores and its relation to the clinical utility was recently highlighted by Vulgaris et al. [43] who stated that in addition to the predictive performance, the components of each score and its formulas are crucial factors for the clinical utility of any risk score. Interestingly it is not AFP cut-off but its post-treatment changes and dynamics during the follow up. Although AFP is the most widely used biomarker in HCC surveillance, it is not included in the international guidelines based on its suboptimal sensitivity and specificity [4547]. However, recently several reports confirmed longitudinal AFP measurement rather than an absolute cut-off value [47, 48] may further increase the sensitivity of HCC detection. Based on these reports and our findings, we suggest that a good score for HCC risk prediction should include the dynamics of AFP during the follow up. This suggestion may be reinforced by the observation that the scores of Watanabe et al, (pretreatment), Fan et al (aMAP score), and Sharma et al (THRI score) which did not include AFP in their components were not clinically useful in our patient cohort although they displayed the highest statistical performance among all studied scores.

The strength of this study is that it is the first direct comparison of recently published HCC risk prediction scores in $\mathrm{CHC}$. This work was done in the same large cohort of $\mathrm{CHC}$ patients with follow up period more than five years allowing assessment of the statistical performance, applicability, clinical utility, 
and potential cost-effectiveness of these scores. The results of this work may pave the way for related methodology together with objective and validated clinical interpretation of HCC risk scores.

The study has some limitations; it reflects the judgment of one single center and most patients were predominantly genotype 4 so validation in cohorts of different ethnicities and other HCV-genotypes may be required before any further recommendations.

In conclusion, ADRES, GES score, GES algorithm, Watanabe (post-treatment) scores seem to offer high predictability and clinical utility for HCC in CHC patients. The dynamics of AFP as a component of these four scores may explain the good clinical usefulness when compared to other scores.

\section{Declarations}

Data Availability: Data are available upon request

Animal Research (Ethics): NA

Consent to Participate (Ethics): The protocol was approved by the Institutional Research Board of ELRIAH (IORG0008819, IRB00010534) in accordance with the local regulations

Consent to Publish (Ethics): Accepted to be published

Plant Reproducibility: NA

Clinical Trials Registration: Registered at Clinical Research Centre in Egyptian Liver Research Institute and Hospital (ELRIAH)

\section{Author Contributions:}

GS designed the study. GS \& RS supervised clinical work. NM performed the statistical analyses. GS, NM, RS, AH and ME interpreted the data. AH supervised the laboratory work. All authors drafted the paper provided input into the manuscript and approved the final version.

Conflicts of interest: The authors declare no conflicts of interest

Funding sources: NA

\section{References}

1. WHO. Global hepatitis report. 2017. Geneva: World Health Organization; 2017. http://www.who.int/hepatitis/publications/global-hepatitisreport2017/en/.

2. European Association for the Study of the Liver. EASL Clinical Practice Guidelines: Management of hepatocellular carcinoma. J Hepatol. 2018;69(1):182-236.

3. Li DK, Ren Y, Fierer DS, et al. The short-term incidence of hepatocellular carcinoma is not increased after hepatitis $C$ treatment with direct-acting antivirals: An ERCHIVES study. Hepatology. 2018;67(6):2244-53.

4. Carrat $\mathrm{F}$, Fontaine $\mathrm{H}$, Dorival $\mathrm{C}$, et al. Clinical outcomes in patients with chronic hepatitis $\mathrm{C}$ after direct-acting antiviral treatment: a prospective cohort study. Lancet. 2019;393(10179):1453-64.

5. Ide T, Koga H, Nakano M, et al. Direct-acting antiviral agents do not increase the incidence of hepatocellular carcinoma development: a prospective, multicenter study. Hepatol Int. 2019;13:293-301.

6. Shiha G, Mousa N, Soliman R, et al. Incidence of HCC in chronic hepatitis C patients with advanced hepatic fibrosis who achieved SVR following DAAs: A prospective study. J Viral Hepat. 2020;00:1-9.

7. European Association for the Study of the Liver. EASL recommendations on treatment of hepatitis C 2018. J Hepatol. 2018;69:461-511.

8. Ghany MG, Morgan TR, et al. Hepatitis C guidance 2019 update: American Association for the Study of Liver Diseases-Infectious Diseases Society of America recommendations for testing, managing, and treating hepatitis C virus infection. Hepatology. 2020;71:686-721.

9. Sarasin FP, Giostra E, Hadengue A. Cost-effectiveness of screening for detection of small hepatocellular carcinoma in western patients with ChildPugh class A cirrhosis. Am J Med. 1996 Oct;101(4):422-34.

10. Mittal S, Kanwal F, Ying J, et al. Effectiveness of surveillance for hepatocellular carcinoma in clinical practice: a United States cohort. J Hepatol. 2016;65:1148-54.

11. loannou G, HCC surveillance after SVR in patients with F3/F4 fibrosis Journal of Hepatology 2021 vol. 74 j $458-465$.

12. CIOMS/WHO. International Ethical Guidelines for Biomedical Research Involving Human Subjects. Geneva: CIOMS; 1993.

13. Shiha G, Seif S, Maher M, et al. Comparison between transient elastography (Fibroscan) and liver biopsy for the diagnosis of hepatic fibrosis in chronic hepatitis genotype 4. Egyptian Liver Journal. 2014;4(4):106-11.

14. European Association for the Study of the Liver. EASL Clinical Practice Guidelines: management of hepatocellular carcinoma. J Hepatol. 2018 Jul;69(1):182-236. 
15. Heimbach JK, Kulik LM, Finn RS, et al. AASLD guidelines for the treatment of hepatocellular carcinoma. Hepatology. 2018;67:358-80.

16. Omata M, Cheng AL, Kokudo N, et al. Asia-Pacific clinical practice guidelines on the management of hepatocellular carcinoma: a 2017 update. Hepatol Int. 2017;11:317-70.

17. Mandrekar JN. Receiver Operating Characteristic Curve in Diagnostic Test Assessment. J Thorac Oncol. 2010 Sep;5(9):1315-6.

18. Trevethan R. Sensitivity, Specificity, Values P. Foundations, Pliabilities, and Pitfalls in Research and Practice. Front Public Health. 2017;5:307.

19. Harrell FE Jr, Califf RM, Pryor DB, et al. Evaluating the yield of medical tests. JAMA. 1982;247:2543-6.

20. Hosmer DW Jr, Lemeshow S, Sturdivant RX. Applied logistic regression: John Wiley \& Sons, 2013.

21. Glen S. 2016. C-Statistic: Definition, Examples, Weighting and Significance. https://www.statisticshowto.com/c-statistic/.

22. Degasperi E, Galmozzi E, Pelusi S, et al. Hepatic fat - Genetic risk score predicts hepatocellular carcinoma in HCV cirrhotic patients treated with DAAs. Hepatology. 2020 Aug 6.

23. Matsuura K, Sawai H, Ikeo K, et al. Genome-Wide Association Study Identifies TLL1 Variant Associated With Development of Hepatocellular Carcinoma After Eradication of Hepatitis C Virus Infection. Gastroenterology. 2017 May;152(6):1383-1394.

24. lio E, Matsuura K, Shimada N, et al. TLL1 variant associated with development of hepatocellular carcinoma after eradication of hepatitis C virus by interferon-free therapy. J Gastroenterol. 2019 Apr;54(4):339-46.

25. Simili A, Mazzella G, Ravaioli F, et al. Interleukin 28 Polymorphisms and Hepatocellular Carcinoma Development after Direct Acting Antiviral Therapy for Chronic Hepatitis C. J Gastrointestin Liver Dis. 2019 Dec 9;28(4):449-456.

26. Qin S, Wang J, Zhou C, et al. The influence of interleukin 28B polymorphisms on the risk of hepatocellular carcinoma among patients with HBV or HCV infection: An updated meta-analysis. Med (Baltim). 2019 Sep;98(38):e17275.

27. Luo X, Wang Y, Shen A, et al. Relationship between the rs 2596542 polymorphism in the MICA gene promoter and HBV/HCV infection-induced hepatocellular carcinoma: Ameta-analysis. BMC Med Genet. 2019 Aug;16(1):142. 20(.

28. Liu W, Ma N, Zhao D, et al. Correlation between the DEPDC5 rs1012068 polymorphism and the risk of HBV-related hepatocellular carcinoma. Clin Res Hepatol Gastroenterol. 2019 Aug;43(4):446-50.

29. Alonso S, Manzano ML, Gea F, et al. A model based on non-invasive markers predicts very low hepatocellular carcinoma risk after viral response in HCV-advanced fibrosis. Hepatology. 2020 Oct 6.

30. Ganne-Carrié N, Layese R, Bourcier V, et al. Nomogram for individualized prediction of hepatocellular carcinoma occurrence in hepatitis $\mathrm{C}$ virus cirrhosis (ANRS C012 CirVir). Hepatology. 2016 Oct;64(4):1136-47.

31. El-Serag HB, Kanwal F, Davila JA, et al. A new laboratory-based algorithm to predict development of hepatocellular carcinoma in patients with hepatitis C and cirrhosis. Gastroenterology. 2014 May;146(5):1249-55.e1.

32. loannou GN, Green PK, Beste LA, et al. Development of models estimating the risk of hepatocellular carcinoma after antiviral treatment for hepatitis C. J Hepatol. 2018 Nov;69(5):1088-98.

33. Sharma SA, Kowgier M, Hansen BE, et al. Toronto HCC risk index: A validated scoring system to predict 10 -year risk of HCC in patients with cirrhosis. J Hepatol. 2017 Aug;24;S0168-8278(17):32248-1.

34. Watanabe T, Tokumoto Y, Joko K, et al. Predictors of hepatocellular carcinoma occurrence after direct-acting antiviral therapy in patients with hepatitis C virus infection. Hepatol Res. 2019 Feb;49(2):136-46.

35. Hu CC, Weng CH, Hua MC, et al. New Scoring Method to Predict Risk of Hepatocellular Carcinoma in Patients with Chronic Hepatitis C After Pegylated Interferon and Ribavirin Therapy. J Interferon Cytokine Res. 2020 Feb;40(2):82-91.

36. Tani J, Morishita A, Sakamoto T, et al. Simple scoring system for prediction of hepatocellular carcinoma occurrence after hepatitis $\mathrm{C}$ virus eradication by direct-acting antiviral treatment: All Kagawa Liver Disease Group Study. Oncol Lett. 2020 Mar;19(3):2205-12.

37. Fan R, Papatheodoridis G, Sun J, et al. aMAP risk score predicts hepatocellular carcinoma development in patients with chronic hepatitis. J Hepatol. 2020 Jul 21;S0168-8278(20)30478-5.

38. Hiraoka A, Kumada T, Ogawa C, et al. Proposed a simple score for recommendation of scheduled ultrasonography surveillance for hepatocellular carcinoma after Direct Acting Antivirals: multicenter analysis. J Gastroenterol Hepatol. 2019 Feb;34(2):436-41.

39. Abe K, Wakabayashi H, Nakayama H, et al. Factors associated with hepatocellular carcinoma occurrence after HCV eradication in patients without cirrhosis or with compensated cirrhosis. PLoS One. 2020 Dec 7;15(12):e0243473.

40. Shiha G, Waked I, Soliman R, et al. GES: A validated simple score to predict risk of HCC in patients with HCV-GT4 associated advanced liver fibrosis after oral antivirals. Liver Int. 2020 Sep 18; 40:2828-2833.

41. Shiha G, Soliman R, Mikhail NNH, et al. Development of a simple dynamic algorithm for individualized HCC risk-based surveillance using pre- and post-treatment GES score. Paper accepted for publication in Liver Int. May 2021.

42. Chun HS, Kim BK, Park JY, et al. Design and validation of risk prediction model for hepatocellular carcinoma development after sustained virological response in patients with chronic hepatitis C. Eur J Gastroenterol Hepatol. 2020 Mar;32(3):378-85.

43. Voulgaris T, Papatheodoridi M, Lampertico P, et al. Clinical utility of hepatocellular carcinoma risk scores in chronic hepatitis B. Liver Int. 2020 Mar;40(3):484-95.

44. Fan R, Yin X, Hou J. Reply to "External validation of aMAP risk score in Chronic hepatitis C genotype 4 patients with liver cirrhosis who achieved SVR following DAAs". J Hepatol. 2021 Jan 13;S0168-8278(21)00011 - 8.

Page $8 / 15$ 
45. Bruix J, Sherman M, American Association for the Study of Liver Diseases. Management of hepatocellular carcinoma: an update. Hepatology. 2011 Mar;53(3):1020-2.

46. European Association For The Study Of The Liver; European Organisation For Research And Treatment Of Cancer. EASL-EORTC clinical practice guidelines: management of hepatocellular carcinoma. J Hepatol. 2012 Apr;56(4):908-43.

47. Chang TS, Wu YC, Tung SY, et al. Alpha-Fetoprotein Measurement Benefits Hepatocellular Carcinoma Surveillance in Patients with Cirrhosis. Am J Gastroenterol. 2015 Jun;110(6):836-44.

48. Biselli M, Conti F, Gramenzi A, et al. A new approach to the use of alpha-fetoprotein as surveillance test for hepatocellular carcinoma in patients with cirrhosis. Br J Cancer. 2015 Jan;6(1):69-76. 112(.

\section{Tables}

Table (1): Scores used in the current study for HCC risk stratification in $\mathrm{CHC}$ patients 


\begin{tabular}{|c|c|c|c|c|c|c|c|c|c|c|c|}
\hline Score & Data set & $\begin{array}{l}\text { All } \\
\text { patients }\end{array}$ & $\mathrm{HCC}$ & $\begin{array}{l}\text { Median } \\
\text { FU }\end{array}$ & Etiology & Centers & $\begin{array}{l}\text { Score } \\
\text { components }\end{array}$ & Categories & $\begin{array}{l}\text { No. / } \\
\text { group }\end{array}$ & HCC IR & $\begin{array}{l}\text { Harrell's } \\
\mathrm{c}\end{array}$ \\
\hline \multirow{2}{*}{$\begin{array}{l}\text { Sharma } \\
\text { et al. } \\
(2018)\end{array}$} & \multirow{3}{*}{$\begin{array}{l}\text { Derivation } \\
(2000- \\
2009)\end{array}$} & \multirow{3}{*}{$\begin{array}{l}2079 \\
\text { F4 }\end{array}$} & \multirow[t]{3}{*}{226} & \multirow[t]{3}{*}{$5.9 \mathrm{y}$} & \multirow{3}{*}{$\begin{array}{l}\text { HBV, } \\
\text { HCV, } \\
\text { ALD, } \\
\text { NAFLD, } \\
\text { AlH, } \\
\text { PBS, } \\
\text { PSC, } \\
\text { Other }\end{array}$} & \multirow{3}{*}{$\begin{array}{l}\text { One } \\
\text { (Canada) }\end{array}$} & \multirow{3}{*}{$\begin{array}{l}\text { Age, } \\
\text { etiology, } \\
\text { sex, PLT }\end{array}$} & Low & \multirow[t]{3}{*}{ NA } & $1.2 \% / 5 y$ & \multirow[t]{3}{*}{0.76} \\
\hline & & & & & & & & Intermediate & & $4.4 \% / 5 y$ & \\
\hline \multirow[t]{4}{*}{$\begin{array}{l}\text { THRI } \\
\text { score [33] }\end{array}$} & & & & & & & & High & & $15.4 \% / 5 y$ & \\
\hline & \multirow[t]{3}{*}{ Validation } & \multirow{3}{*}{$\begin{array}{l}1144, \\
\text { F4 }\end{array}$} & \multirow[t]{3}{*}{107} & \multirow[t]{3}{*}{$7.3 y$} & \multirow{3}{*}{$\begin{array}{l}\text { HBV, } \\
\text { HCV, } \\
\text { PBS }\end{array}$} & \multirow{3}{*}{$\begin{array}{l}\text { Four } \\
\text { (Netherlands) }\end{array}$} & \multirow{3}{*}{$\begin{array}{l}\text { Age, } \\
\text { etiology, } \\
\text { sex, PLT }\end{array}$} & Low & \multirow[t]{3}{*}{ NA } & $1.1 \% / 5 y$ & \multirow[t]{3}{*}{0.77} \\
\hline & & & & & & & & Intermediate & & $4.9 \% / 5 y$ & \\
\hline & & & & & & & & High & & $13.1 \% / 5 y$ & \\
\hline \multirow{4}{*}{$\begin{array}{l}\text { Watanabe } \\
\text { et al. } \\
(2019) \\
{[34]}\end{array}$} & \multirow{4}{*}{$\begin{array}{l}\begin{array}{l}\text { Pre- } \\
\text { treatment }\end{array} \\
(2014- \\
2017)\end{array}$} & \multirow[t]{4}{*}{1174} & \multirow[t]{4}{*}{33} & \multirow[t]{4}{*}{$537 d$} & \multirow[t]{4}{*}{$\begin{array}{l}\mathrm{HCV} \\
\text { (DAA) }\end{array}$} & $\begin{array}{l}10 \text { Hospitals } \\
\text { (Japan) }\end{array}$ & $\begin{array}{l}\text { FIB4, Alb, } \\
\text { sex }\end{array}$ & Low & $\begin{array}{l}384 \\
(327 \%)\end{array}$ & $0.4 \% 2 y$ & NA \\
\hline & & & & & & & & Intermediate & & $4.4 \% 2 y$ & \\
\hline & & & & & & & & High & $(62.2 \%)$ & $16.4 \% 2 y$ & \\
\hline & & & & & & & & & $\begin{array}{l}60 \\
(5.1 \%)\end{array}$ & & \\
\hline $\begin{array}{l}\text { Watanabe } \\
\text { et al. }\end{array}$ & $\begin{array}{l}\text { Post- } \\
\text { treatment }\end{array}$ & 553 & & & $\begin{array}{l}\mathrm{HCV} \\
\text { (DAA) }\end{array}$ & $\begin{array}{l}10 \text { Hospitals } \\
\text { (Japan) }\end{array}$ & FIB4, AFP & Low & & $0.4 \% 2 y$ & NA \\
\hline (2019) & (2014- & & & & & & & Intermediate & & $3.2 \% 2 y$ & \\
\hline [37] & 2017) & & & & & & & High & & $14.4 \% 2 y$ & \\
\hline Hu et al. & Derivation & 665 & 65 & $5.4 \mathrm{y}$ & $\begin{array}{l}\mathrm{HCV} \\
\text { (INF) }\end{array}$ & One (Taiwan) & $\begin{array}{l}\text { Age, } \\
\text { bilirubin, }\end{array}$ & & $\begin{array}{l}453 \\
(68.1 \%)\end{array}$ & $4.2 \% 10 y$ & $\begin{array}{l}\text { AUROC } \\
=0.884\end{array}$ \\
\hline $\begin{array}{l}(2019) \\
{[35]}\end{array}$ & $\begin{array}{l}(2002- \\
2016)\end{array}$ & & & & & & $\begin{array}{l}\text { AFP, SVR, } \\
\text { Cirrhosis }\end{array}$ & High & $\begin{array}{l}212 \\
(31.9 \%)\end{array}$ & $\begin{array}{l}30.4 \% \\
10 y\end{array}$ & \\
\hline & Validation & 78 & 13 & & HBV & One (Taiwan) & $\begin{array}{l}\text { Age, } \\
\text { bilirubin }\end{array}$ & Low & $\begin{array}{l}51 \\
(65.4 \%)\end{array}$ & $8.3 \% 10 y$ & NA \\
\hline & $\begin{array}{l}(2002- \\
2016)\end{array}$ & & & & & & $\begin{array}{l}\text { AFP, SVR, } \\
\text { Cirrhosis }\end{array}$ & High & $\begin{array}{l}27 \\
(34.6 \%)\end{array}$ & $\begin{array}{l}36.2 \% \\
10 y\end{array}$ & \\
\hline Tani et al. & $\begin{array}{l}\text { Post- } \\
\text { treatment }\end{array}$ & 1088 & 26 & $13.8 \mathrm{~m}$ & $\begin{array}{l}\mathrm{HCV} \\
\text { (DAA) }\end{array}$ & Six (Japan) & $\begin{array}{l}\text { Age, Follow } \\
\text { up AFP }\end{array}$ & & $\begin{array}{l}630 \\
(57.9 \%)\end{array}$ & & NA \\
\hline $\begin{array}{l}(2020) \\
{[36]}\end{array}$ & & & & & & & & Intermediate & 402 & $6.27 \% 2 y$ & \\
\hline & 2018) & & & & & & & High & $(36.9 \%)$ & $\begin{array}{l}18.37 \% \\
2 y\end{array}$ & \\
\hline & & & & & & & & & $\begin{array}{l}56 \\
(5.1 \%)\end{array}$ & & \\
\hline $\begin{array}{l}\text { Fan et al. } \\
(2020)\end{array}$ & Training & 3688 & 95 & $42.7 \mathrm{~m}$ & HBV & One group & $\begin{array}{l}\text { Age, sex, } \\
\text { Alb, Plt, }\end{array}$ & & $\begin{array}{l}2158 \\
(58.9 \%)\end{array}$ & $0.8 \% 5 y$ & 0.82 \\
\hline & $\begin{array}{l}(2014- \\
2018)\end{array}$ & & & & & & Bilirubin & Intermediate & 1181 & $5.1 \% 5 y$ & \\
\hline score [37] & & & & & & & & High & $(32.3 \%)$ & $19.9 \% 5 y$ & \\
\hline & & & & & & & & & $\begin{array}{l}323 \\
(8.8 \%)\end{array}$ & & \\
\hline & Validation & 13686 & 536 & $\begin{array}{l}33.6- \\
105.4\end{array}$ & $\begin{array}{l}\mathrm{HBV}, \\
\mathrm{HCV} \\
\mathrm{NVH}\end{array}$ & Nine trials & $\begin{array}{l}\text { Age, sex, } \\
\text { Alb, Plt, } \\
\text { Bilirubin }\end{array}$ & Low & $\begin{array}{l}5255 \\
(39.4 \%)\end{array}$ & $\begin{array}{l}0.0 .8 \% \\
5 y\end{array}$ & $\begin{array}{l}0.82- \\
0.87\end{array}$ \\
\hline & 2018) & & & $\mathrm{m}$ & & countries) & & High & $\begin{array}{l}5348 \\
(40.1 \%)\end{array}$ & $\begin{array}{l}1.5-4.8 \% \\
5 y\end{array}$ & \\
\hline & & & & & & & & & $\begin{array}{l}2721 \\
(20.4 \%)\end{array}$ & $\begin{array}{l}8.1- \\
17.8 \% 5 y\end{array}$ & \\
\hline $\begin{array}{l}\text { Hiraoka et } \\
\text { al. (2019) }\end{array}$ & Training & 484 & 22 & $16.3 \mathrm{~m}$ & $\begin{array}{l}\mathrm{HCV} \\
\text { (DAA) }\end{array}$ & $\begin{array}{l}\text { Three } \\
\text { (Japan) }\end{array}$ & $\begin{array}{l}\text { Sex, FIB4, } \\
\text { Follow up }\end{array}$ & Very low & $\begin{array}{l}134 \\
(27.7 \%)\end{array}$ & $0.0 \% 2 y$ & 0.835 \\
\hline $\begin{array}{l}\text { ADRES } \\
\text { score }\end{array}$ & $\begin{array}{l}(2014- \\
2017)\end{array}$ & & & & & & AFP & $\begin{array}{l}\text { Low } \\
\text { Intermediate }\end{array}$ & $\begin{array}{l}225 \\
(46.5 \%)\end{array}$ & $\begin{array}{l}2.1 \% 2 y \\
15.9 \% 2 y\end{array}$ & \\
\hline [38] & & & & & & & & High & $\begin{array}{l}100 \\
(20.7 \%)\end{array}$ & $28.1 \% 2 y$ & \\
\hline & & & & & & & & & $\begin{array}{l}25 \\
(5.2 \%)\end{array}$ & & \\
\hline & Validation & 585 & 14 & $16.3 \mathrm{~m}$ & $\begin{array}{l}\mathrm{HCV} \\
\text { (DAA) }\end{array}$ & One (Japan) & $\begin{array}{l}\text { Sex, FIB4, } \\
\text { Follow up }\end{array}$ & Very low & 225 & $0.0 \% 2 y$ & 0.899 \\
\hline & & & & & & & AFP & Low & & $0.7 \% 2 y$ & \\
\hline
\end{tabular}

Page 10/15 


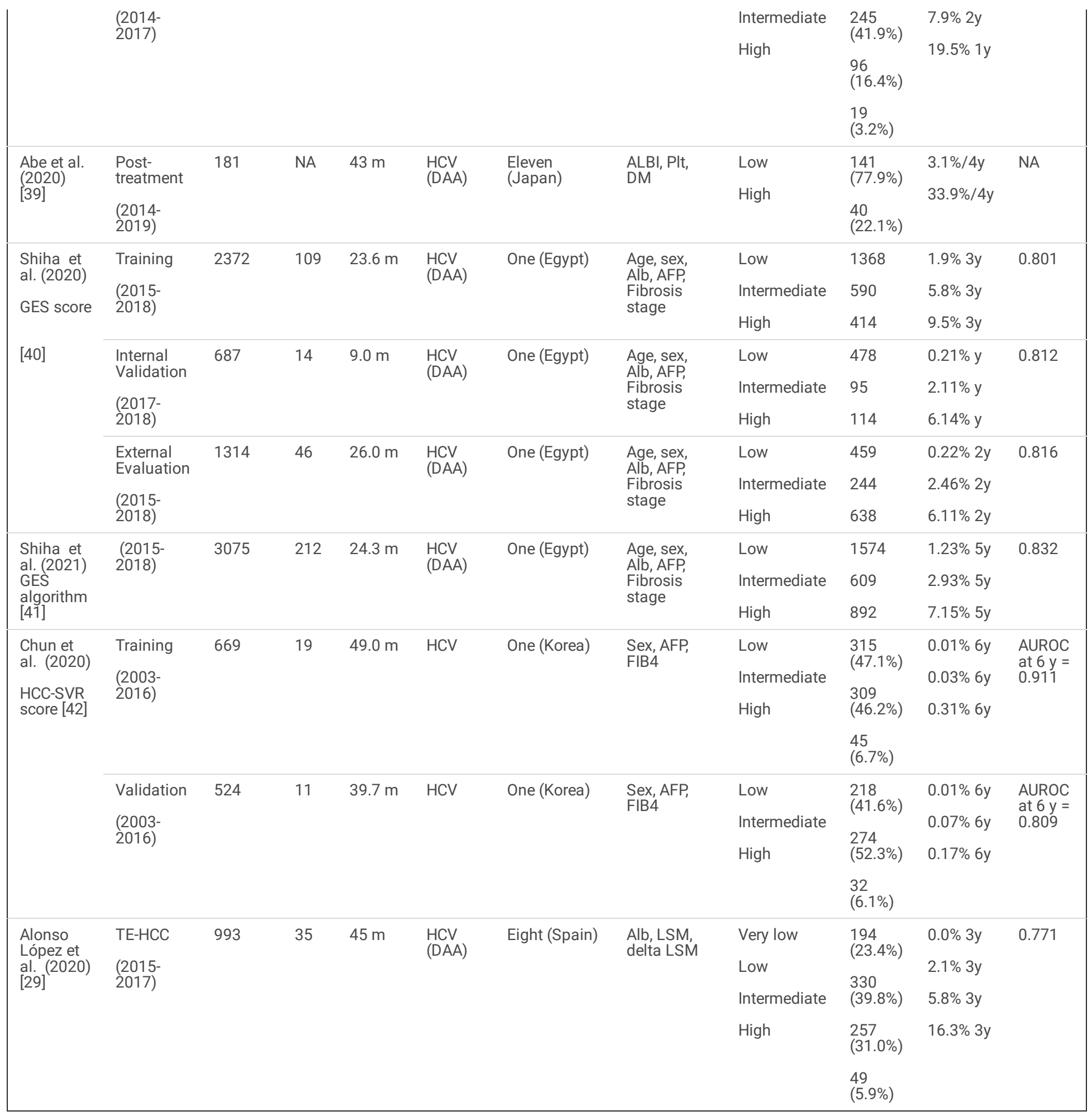

Table (2): Performance of different risk scores in our cohort 


\begin{tabular}{|c|c|c|c|c|}
\hline Score & Risk group & No. / group (\%) & $\mathrm{HCC} /$ group & $\begin{array}{l}\text { HCC } 5 \text { y } \\
\text { cumulative IR } \\
(95 \% \mathrm{Cl})\end{array}$ \\
\hline \multirow[t]{3}{*}{ Sharma et al. THRI score } & Low & $766(24.9 \%)$ & 9 & $0.51(0.23-1.02)$ \\
\hline & Intermediate & $2072(67.4 \%)$ & 165 & 3.25 (2.73-3.84) \\
\hline & High & $237(7.7 \%)$ & 38 & $6.47(4.45-9.12)$ \\
\hline Watanabe et al. & Low & $676(22.0 \%)$ & 6 & $0.40(0.10-1.09)$ \\
\hline \multirow[t]{2}{*}{ Pre-treatment score } & Intermediate & 2077 (67.5\%) & 126 & $2.42(1.86-3.09)$ \\
\hline & High & $322(10.5 \%)$ & 80 & $8.29(5.95-11.25)$ \\
\hline Watanabe et al. & Low & $1462(47.5 \%)$ & 38 & $1.10(0.68-1.68)$ \\
\hline \multirow[t]{2}{*}{ Post-treatment score } & Intermediate & 1227 (39.9\%) & 97 & $3.11(2.33-4.08)$ \\
\hline & High & $386(12.6 \%)$ & 77 & 7.58 (5.44-10.30) \\
\hline \multirow[t]{2}{*}{ Hu et al. score } & Low & $1814(59.0 \%)$ & 70 & 1.70 (1.29-2.19) \\
\hline & High & $1261(41.0 \%)$ & 142 & $4.60(3.80-5.51)$ \\
\hline \multirow[t]{3}{*}{ Tani et al. score } & Low & $2178(70.8 \%)$ & 94 & $2.13(1.73-2.59)$ \\
\hline & Intermediate & $885(28.8 \%)$ & 116 & $6.48(5.38-7.77)$ \\
\hline & High & $12(0.4 \%)$ & 2 & $11.48(1.93-37.93)$ \\
\hline \multirow[t]{3}{*}{ Fan et al. aMAP score } & Low & $521(16.9 \%)$ & 4 & $0.35(0.09-0.95)$ \\
\hline & Intermediate & $1315(42.8 \%)$ & 38 & $1.17(0.79-1.68)$ \\
\hline & High & $1239(40.3 \%)$ & 170 & $5.40(4.50-6.44)$ \\
\hline \multirow[t]{4}{*}{ Hiraoka et al. ADRES score } & Very low & $504(16.4 \%)$ & 6 & $0.54(0.14-1.46)$ \\
\hline & Low & $1244(40.5 \%)$ & 36 & $1.18(0.72-1.83)$ \\
\hline & Intermediate & $1032(33.6 \%)$ & 96 & $3.64(2.72-4.79)$ \\
\hline & High & $295(9.6 \%)$ & 74 & $9.08(6.49-12.38)$ \\
\hline \multirow[t]{2}{*}{ Abe et al. score } & Low & $2604(84.7 \%)$ & 136 & $2.51(2.00-3.10)$ \\
\hline & High & $471(15.3 \%)$ & 76 & $6.43(4.76-8.50)$ \\
\hline \multirow[t]{3}{*}{ Shiha et al. GES pre-treatment score } & Low & $1857(60.4 \%)$ & 59 & $1.66(1.27-2.12)$ \\
\hline & Intermediate & $719(23.4 \%)$ & 71 & $4.45(3.50-5.57)$ \\
\hline & High & $499(16.2 \%)$ & 82 & $7.64(6.11-9.43)$ \\
\hline \multirow[t]{3}{*}{ Shiha et al. GES post-treatment score } & Low & $1764(57.4 \%)$ & 46 & 1.35 (1.00-1.79) \\
\hline & Intermediate & $944(30.7 \%)$ & 68 & $3.49(2.73-4.40)$ \\
\hline & High & $367(11.9 \%)$ & 98 & $11.09(9.05-13.45)$ \\
\hline \multirow[t]{3}{*}{ Shiha et al. GES algorithm } & Low & $1574(51.2 \%)$ & 37 & $1.23(0.88-1.67)$ \\
\hline & Intermediate & $609(19.8 \%)$ & 38 & $2.93(2.11-3.99)$ \\
\hline & High & $892(29.0 \%)$ & 137 & $7.15(6.03-8.43)$ \\
\hline \multirow[t]{3}{*}{ Chun et al. HCC-SVR score } & Low & $957(31.1 \%)$ & 31 & $1.75(1.21-2.45)$ \\
\hline & Intermediate & 1659 (54.0\%) & 120 & $3.52(2.92-4.21)$ \\
\hline & High & $459(14.9 \%)$ & 61 & 5.79 (4.47-7.39) \\
\hline \multirow[t]{4}{*}{ Alonso López et al. TE-HCC score } & Very low & $490(15.9 \%)$ & 15 & $1.09(0.44-2.27)$ \\
\hline & Low & $848(27.6 \%)$ & 42 & $1.82(1.10-2.85)$ \\
\hline & Intermediate & $1236(40.2 \%)$ & 98 & $2.90(2.10-3.90)$ \\
\hline & High & $501(16.3 \%)$ & 57 & $3.65(2.37-5.39)$ \\
\hline
\end{tabular}


Table (3): Accuracy for prediction of hepatocellular carcinoma development in $\mathrm{CHC}$ patients using different scores

\begin{tabular}{|c|c|c|c|c|c|c|c|c|}
\hline Score & $\begin{array}{l}\text { Harrell's } \\
\mathrm{C}\end{array}$ & $\begin{array}{l}\text { Log Rank } \\
\mathrm{p}\end{array}$ & $\begin{array}{l}\text { Sensitivity\# } \\
(95 \% \mathrm{Cl})\end{array}$ & $\begin{array}{l}\text { Specificity } \\
(95 \% \mathrm{Cl})\end{array}$ & $\begin{array}{l}\text { PPV }^{\#} \\
(95 \% \mathrm{Cl})\end{array}$ & $\begin{array}{l}\text { NPV }^{\#} \\
(95 \% \mathrm{Cl})\end{array}$ & $\begin{array}{l}\text { Accuracy } \\
(95 \% \mathrm{Cl})\end{array}$ & $\begin{array}{l}\text { AUROC } \\
(95 \% \mathrm{Cl})\end{array}$ \\
\hline Sharma et al. THRI score & 0.6505 & $<0.001$ & $\begin{array}{l}95.75 \\
(92.13- \\
97.75)\end{array}$ & $\begin{array}{l}26.44 \\
(24.86- \\
28.09)\end{array}$ & $\begin{array}{l}8.78 \\
(7.70- \\
10.02)\end{array}$ & $\begin{array}{l}98.83 \\
(97.78- \\
99.38)\end{array}$ & $\begin{array}{l}31.22 \\
(29.61- \\
32.88)\end{array}$ & $\begin{array}{l}0.739 \\
(0.704- \\
0.775) \\
P<0.001\end{array}$ \\
\hline $\begin{array}{l}\text { Watanabe et al. } \\
\text { Pre-treatment score }\end{array}$ & 0.6406 & $<0.001$ & $\begin{array}{l}97.17 \\
(93.96- \\
98.70)\end{array}$ & $\begin{array}{l}23.40 \\
(21.89- \\
24.99)\end{array}$ & $\begin{array}{l}8.59 \\
(7.53-9.78)\end{array}$ & $\begin{array}{l}99.11 \\
(98.08- \\
99.59)\end{array}$ & $\begin{array}{l}28.49 \\
(26.92- \\
30.11)\end{array}$ & NA \\
\hline $\begin{array}{l}\text { Watanabe et al. } \\
\text { Post-treatment score }\end{array}$ & 0.6693 & $<0.001$ & $\begin{array}{l}82.08 \\
(73.36- \\
86.65)\end{array}$ & $\begin{array}{l}22.28 \\
(20.80- \\
23.85)\end{array}$ & $\begin{array}{l}7.25 \\
(6.28-8.36)\end{array}$ & $\begin{array}{l}94.38 \\
(92.38- \\
95.88)\end{array}$ & $\begin{array}{l}26.41 \\
(24.88- \\
27.99)\end{array}$ & NA \\
\hline Hu et al. score & 0.6158 & $<0.001$ & $\begin{array}{l}66.98 \\
(60.40- \\
72.96)\end{array}$ & $\begin{array}{l}60.92 \\
(59.11- \\
62.69)\end{array}$ & $\begin{array}{l}11.26 \\
(9.63- \\
13.12)\end{array}$ & $\begin{array}{l}96.14 \\
(95.15- \\
96.93)\end{array}$ & $\begin{array}{l}61.33 \\
(59.60- \\
63.04)\end{array}$ & $\begin{array}{l}0.691 \\
(0.651- \\
0.731) \\
P<0.001\end{array}$ \\
\hline Tani et al. score & 0.6388 & $<0.001$ & $\begin{array}{l}55.66 \\
(48.93- \\
62.19)\end{array}$ & $\begin{array}{l}72.79 \\
(71.13- \\
74.39)\end{array}$ & $\begin{array}{l}13.15 \\
(11.10- \\
15.52)\end{array}$ & $\begin{array}{l}95.68 \\
(94.75- \\
96.46)\end{array}$ & $\begin{array}{l}71.61 \\
(69.99- \\
73.18)\end{array}$ & NA \\
\hline Fan et al. aMAP score & 0.6984 & $<0.001$ & $\begin{array}{l}98.11 \\
(95.25- \\
99.26)\end{array}$ & $\begin{array}{l}18.06 \\
(16.69- \\
19.51)\end{array}$ & $\begin{array}{l}8.14 \\
(7.15-9.27)\end{array}$ & $\begin{array}{l}99.23 \\
(98.04- \\
99.70)\end{array}$ & $\begin{array}{l}23.58 \\
(22.11- \\
25.11)\end{array}$ & $\begin{array}{l}0.765 \\
(0.728- \\
0.801) \\
P<0.001\end{array}$ \\
\hline Hiraoka et al. ADRES score & 0.7183 & $<0.001$ & $\begin{array}{l}80.19 \\
(71.31- \\
85.00)\end{array}$ & $\begin{array}{l}59.59 \\
(57.78- \\
61.37)\end{array}$ & $\begin{array}{l}12.81 \\
(11.12- \\
14.72)\end{array}$ & $\begin{array}{l}97.60 \\
(96.77- \\
98.22)\end{array}$ & $\begin{array}{l}61.01 \\
(59.27- \\
62.72)\end{array}$ & NA \\
\hline Abe et al. score & 0.5678 & 0.013 & $\begin{array}{l}35.85 \\
(29.70- \\
42.50)\end{array}$ & $\begin{array}{l}86.20 \\
(84.89- \\
87.42)\end{array}$ & $\begin{array}{l}16.14 \\
(13.09- \\
19.73)\end{array}$ & $\begin{array}{l}94.78 \\
(93.85- \\
95.57)\end{array}$ & $\begin{array}{l}82.73 \\
(81.36- \\
84.03)\end{array}$ & NA \\
\hline $\begin{array}{l}\text { Shiha et al. GES pre-treatment } \\
\text { score }\end{array}$ & 0.801 & $<0.001$ & $\begin{array}{l}72.17 \\
(65.78- \\
77.77)\end{array}$ & $\begin{array}{l}62.80 \\
(61.01- \\
64.55)\end{array}$ & $\begin{array}{l}12.56 \\
(10.82- \\
14.54)\end{array}$ & $\begin{array}{l}96.82 \\
(95.92- \\
97.53)\end{array}$ & $\begin{array}{l}63.45 \\
(61.73- \\
65.13)\end{array}$ & $\begin{array}{l}0.725 \\
(0.689- \\
0.761) \\
P<0.001\end{array}$ \\
\hline $\begin{array}{l}\text { Shiha et al. GES post-treatment } \\
\text { score }\end{array}$ & 0.828 & $<0.001$ & $\begin{array}{l}78.30 \\
(72.28- \\
83.32)\end{array}$ & $\begin{array}{l}60.01 \\
(58.20- \\
61.79)\end{array}$ & $\begin{array}{l}12.66 \\
(10.97- \\
14.57)\end{array}$ & $\begin{array}{l}97.39 \\
(96.54- \\
98.04)\end{array}$ & $\begin{array}{l}61.27 \\
(59.53- \\
62.98)\end{array}$ & $\begin{array}{l}0.796 \\
(0.765- \\
0.828) \\
P<0.001\end{array}$ \\
\hline Shiha et al. GES algorithm & 0.832 & $<0.001$ & $\begin{array}{l}82.6 \\
(76.9-87.1)\end{array}$ & $\begin{array}{l}53.7 \\
(51.9-55.5)\end{array}$ & $\begin{array}{l}11.7 \\
(10.1-13.4)\end{array}$ & $\begin{array}{l}97.7 \\
(96.8-98.3)\end{array}$ & $\begin{array}{l}55.8 \\
(53.9-57.4)\end{array}$ & NA \\
\hline Chun et al. HCC-SVR score & 0.6038 & 0.053 & $\begin{array}{l}85.38 \\
(79.99- \\
89.50)\end{array}$ & $\begin{array}{l}32.34 \\
(30.65- \\
34.08)\end{array}$ & $\begin{array}{l}8.55 \\
(7.43-9.81)\end{array}$ & $\begin{array}{l}96.76 \\
(95.44- \\
97.71)\end{array}$ & $\begin{array}{l}36.00 \\
(34.32- \\
37.71)\end{array}$ & $\begin{array}{l}0.660 \\
(0.623- \\
0.697) \\
P<0.001\end{array}$ \\
\hline $\begin{array}{l}\text { Alonso López et al. TE-HCC } \\
\text { score }\end{array}$ & 0.5975 & 0.374 & $\begin{array}{l}73.11 \\
(66.77- \\
78.63)\end{array}$ & $\begin{array}{l}44.74 \\
(42.93- \\
46.57)\end{array}$ & $\begin{array}{l}8.92 \\
(7.67- \\
10.36)\end{array}$ & $\begin{array}{l}95.74 \\
(94.52- \\
96.70)\end{array}$ & $\begin{array}{l}46.70 \\
(44.94- \\
48.47)\end{array}$ & NA \\
\hline
\end{tabular}

\# comparing risky patients (high + intermediate risk groups) with less risky patients (low risk group) 
Fig. 1

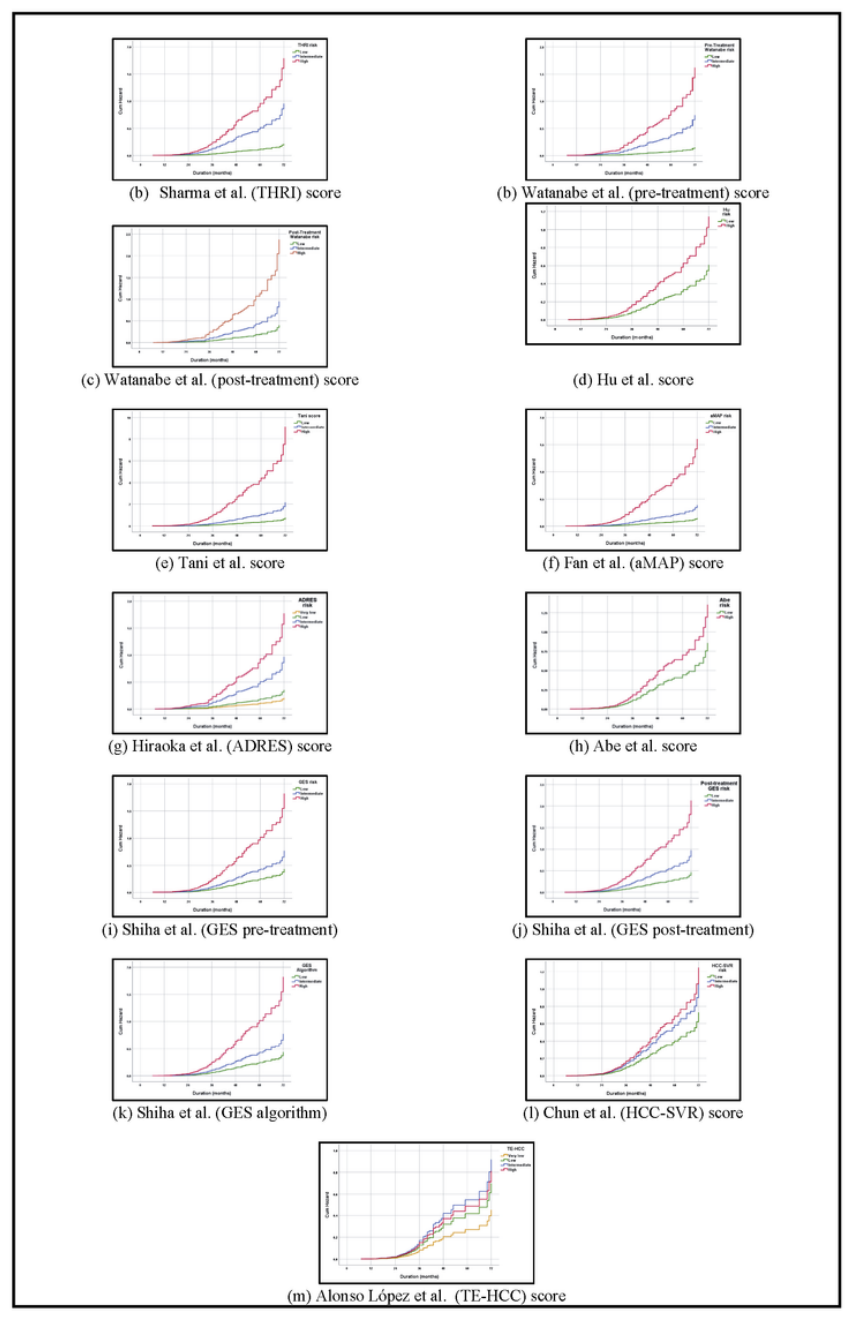

Figure 1

Cumulative risk of $\mathrm{HCC}$ according to different prediction scores

Page 14/15 
Fig. 2

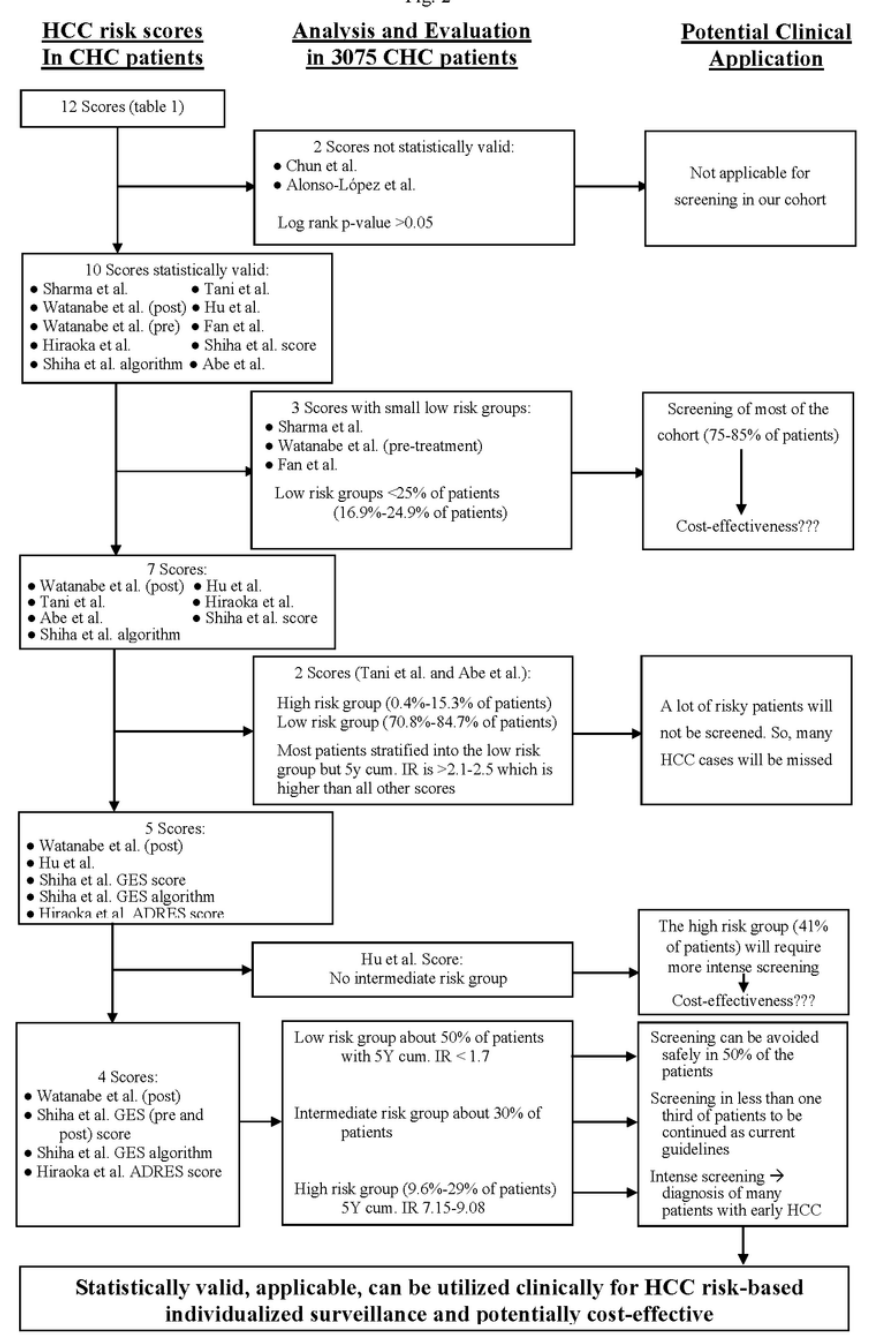

Figure 2

Flowchart of the evaluation and analysis of the twelve scores 